Journal of Ancient Philosophy Vol. VI 2012 Issue 1

\title{
Doubt and Anxiety: An Existentialist Reconstruction of Pyrrhonism
}

\author{
Örsan K. Öymen (Bahcesehir University)
}

The aim of this paper is to develop a potential relation between Pyrrhonism and existentialism. This is possible by establishing either an existentialist reconstruction of Pyrrhonism or a Pyrrhonian reconstruction of existentialism. The necessity of unveiling such a relation derives from: (1) the lack of an epistemological sceptical perspective and a normative ethical position within existentialism; (2) the lack of an accurate analysis of the human being within Pyrrhonism. However, the compatibility of the strong aspects inherent in both schools, the sceptical subjectivist arguments and the normative approach to morality inherent in Pyrrhonism and the analysis of the human being in relation to anxiety, potentiality, becoming, alienation, inauthenticity, authenticity and freedom inherent in existentialism, may show us a new way of looking into the universe and human life.

The aim of this paper is to present a rather odd and unusual but hopefully original analysis on a potential relation between Pyrrhonism and existentialism. The way to do this is my proposal to establish either an existentialist reconstruction of Pyrrhonism or a Pyrrhonian reconstruction of existentialism. The necessity of unveiling such a relation derives from the lack of an epistemological sceptical perspective and a normative ethical position within existentialism as well as from the lack of an accurate analysis of the human being within Pyrrhonism; and the hope that the compatibility of the strong aspects inherent in both schools may show us a new way of looking into the universe and human life.

Understanding this perspective obviously requires an analysis of Pyrrhonism and existentialism; as well as a comparison between them.

Pyrrhonism is an Ancient Greek sceptical philosophical school founded by Pyrrho of Elis. His most prominent followers were Timon, Aenesedimus, Agrippa and Sextus Empiricus and their main targets were Plato, Aristotle, Zeno (of Citium), Epicurus and their followers. Pyrrho, like Socrates, never wrote anything. The writings of Timon, Aenesedimus and 
Journal of Ancient Philosophy Vol. VI 2012 Issue 1

Agrippa are lost and do not exist anymore. The only writings by Pyrrhonian philosophers which survived and are available at present are those of Sextus Empiricus. This makes Sextus Empiricus the most important source of what is known today as Pyrrhonian scepticism.

When we analyze Pyrrhonian scepticism as expressed in the texts of Sextus Empiricus, particularly in his Outlines of Pyrrhonism and Against the Mathematicians (consisting of Against the Logicians, Against the Physicists and Against the Ethicists), we see an abolishment of the duality between appearance and reality, in the sense that the only thing one can be certain of are appearances (phainomena). The sceptic has no doubt about the appearances but only a doubt about a so called reality; or rather a doubt about how things are in themselves; how things are by nature, independent of the human mind. ${ }^{1}$ So the Pyrrhonian sceptic suspends judgement (epoche) both as to whether things are as they appear to us and as to whether things are not as they appear to us.

Appearances in Sextus's texts can both be about sensation and about thought. In other words things appear to our sense perceptions and to our thought and what appears to our sense perceptions and to our thought may differ among different human beings. Appearances are relative. $^{2}$ However this does not mean that the Pyrrhonian sceptic raises doubt about the appearance itself. On the contrary, he gives assent to things, he grants things, he raises no doubt about things, as long as they are in accordance with the appearances. Therefore, when the Pyrrhonian sceptic talks about uttering things without belief (adoxastos), he talks about specific beliefs, not all beliefs, he talks about dogmatic beliefs which transcend the appearances and the limits of the human mind; when the Pyrrhonian sceptic talks about suspending judgement, he talks about specific judgements, not all judgements, he talks about dogmatic judgements which transcend the appearances and the limits of the human mind.

To categorize the statement " $\mathrm{X}$ is $\mathrm{Y}$ in itself, by nature" as one representative of belief and judgement; and to categorize the statement "X appears $\mathrm{Y}$ " not as one representative of belief and judgement is obviously absurd. These two statements differ in structure but both statements represent a belief and a judgement. There is no reason to disqualify a statement

\footnotetext{
${ }^{1}$ Sextus Empiricus: Outlines of Pyrrhonism, Book 1, Section 7-8, 10-11, 14, 20

${ }^{2}$ Sextus Empiricus: Outlines of Pyrrhonism Book 1, Section 14
} 
Journal of Ancient Philosophy Vol. VI 2012 Issue 1

about an appearance as representative of belief and judgement. ${ }^{3}$ The English terms belief and judgement simply do not correspond to the Greek term doxa in the context of Sextus's texts.

For example, the sceptic does not raise any doubt about the fact that honey appears sweet to a particular person if it does so; however he would raise a doubt about whether honey is sweet in itself, by nature. Similarly, in the field of morality, actions and choices appear good or bad to different individuals or different societies; the sceptic does not raise any doubt about the appearance itself, but he does raise doubt about whether actions and choices are

${ }^{3}$ This interpretation of mine is clearly in opposition to the interpretations of Myles Burnyeat, Benson Mates, Michael Williams, Christopher Hookway and Julia Annas. (Myles Burnyeat, The Sceptical Tradition, pg. 119-122; Benson Mates, The Sceptic Way, pg. Vii; Michael Williams, Scepticism, pg. 553; Christopher Hookway, Scepticism, pg. İx and pg. 2; Julia Annas, Hume and Ancient Scepticism, pg. 273 and pg. 279-280). It is also in opposition to Julia Annas's and Jonathan Barnes's translation of adoxastos as "without holding any opinions" and Benson Mates's translation of the same concept as "without belief". (Outlines of Scepticism translated by Julia Annas and Jonathan Barnes; The Sceptic Way. Sextus Empiricus' Outlines of Pyrrhonism translated with an introduction and commentary by Benson Mates). Burnyeat does seem to be aware of this objection (The Sceptical Tradition pg. 133134) but in the end states that there can not be a belief without assuming a concept of truth; Hookway also aware of the same objection presents a similar attitude presenting truth as a necessary precondition of belief (Scepticism, pg. 15.). Mates also mentions a counter position to his own saying that the English term belief may have different meanings and that doxa refers to something more specific about the external world but in the end he insists on translating adoxastos as "without belief" (The Sceptic Way, pg. 60). Williams raises the possibility of a similar objection saying that according to some passages in Sextus the scope of epoche might be seen as limited but in the end concludes that Sextus' scepticism is devoid of a theoretical basis in epistemology (Scepticism, pg. 56). Annas does say that the Pyrrhonian sceptic way is compatible with action according to appearances (Hume and Ancient Scepticism, pg. 275) and that doxa is more tied to truth and rational support (Hume and Ancient Scepticism, pg. 283). However this is in contradiction to what she says in the same article when she claims that the Pyrrhonian sceptic has no position, no position of his own and makes no assertion (Hume and Ancient Scepticism, pg. 273, pg. 279-280) and also in contradiction with her translation of the concept of adoxastos as "without holding any opinions". I think a more accurate and consistent interpretation then those of Burnyeat, Mates, Williams, Hookway and Annas is presented by Gisela Striker, Arne Naess and Nicholas Rescher. (Gisela Striker, Essays on Hellenistic Epistemology and Ethics, pg. 142-145; Arne Naess, Scepticism, pg. 47-48; Nicholas Rescher, Scepticism, pg. 29 and pg. 215-216). My interpretation has an intersecting aspect with that of Striker, Naess and Rescher. The translation of R.G. Bury and Sanford G. Etheridge are also more reflective of Sextus in this aspect when compared to Annas, Barnes and Mates. R.G. Bury translates adoxastos as "undogmatically" and Etheridge either as "undogmatically" or as "without prejudice" (Sextus Empiricus. Outlines of Pyrrhonism translated by R.G. Bury; Hallie, Philip P. -Editor- \& Sanford G. Etheridge -Translator-, Scepticism, Man and God). My proposal is that we can also translate adoxastos as "without beliefs of dogma", "without dogmatic belief", "without belief in dogma" or "without dogmatic opinion" (Örsan K. Öymen, Sextus Empiricus' Problem of Criterion, PhD Thesis, Middle East Technical University, pg 81; Sekstus Empirikus'un 'Pironizmin Ana Hatları' Eserinden Bölümlerin Çevirisi Üzerine, pg. 77). 
Journal of Ancient Philosophy Vol. VI 2012 Issue 1

good or bad by nature, in themselves, independent of the appearance; he does raise doubt about whether the action and choice is representative of an objective and / or universal moral principle, judgement and reality. Judgements about moral issues, about what is good and bad, for example about death, prostitution, incest, masturbation, homosexuality, sexual intercourse in public may differ among Greeks and also among different cultures and societies, such as the Greeks, the Persians, the Egyptians and the Indians. There are no objective and / or universal moral realities. ${ }^{4}$

The only thing we have are the relative appearances which vary among different animals and human beings. Things appear to our sensations and also to our thought; but to establish a connection or disconnection, a correspondence or noncorrespondence between appearance and reality can not be justified; such an attempt can only be a dogmatic one; such an attempt would be the attempt of a dogmatist. A suspense of judgement is necessary both about the essential properties of physical objects, about how things are by nature, how things are in themselves; and also about objective and / or universal moral values, about things good and bad by nature.

The only way to solve this problem of relativity and establish something in the name of reality would be to establish a criterion of truth, which through a proof would enable us to distinguish between true and false and make a selection from the varying relative appearances. However due to the problems of circularity and infinite regress that does not seem possible as well. ${ }^{5}$ To justify a proof with a criterion and a criterion with a proof will lead us into a circular reasoning. To justify a criterion with another criterion or a proof with another proof will lead us into an infinite regress; because each criterion or each proof would itself be in need of a criterion or proof. Basic self-evident assumptions which are immune from a criterion or proof do not seem possible either; if such assumptions would be the case there would not be a relativity among appearances in sensation and thought.

Therefore one must suspend judgement as to anything which goes beyond our appearances, which transcend our appearances. Philosophers who try to establish a realm, a

\footnotetext{
${ }^{4}$ Sextus Empiricus: Outlines of Pyrrhonism Book 3, Section 22-24; Against The Ethicists, Section 1, 3-4

${ }^{5}$ Sextus Empiricus: Outlines of Pyrrhonism Book 1, Section 14-16, Book 2, Section 3-7
} 
Journal of Ancient Philosophy Vol. VI 2012 Issue 1

dimension, a world beyond appearance are dogmatist philosophers. The claim of the Pyrrhonian sceptics is not a dogmatist claim because it is satisfied with mere appearances and raises doubt about so called realities. The Pyrrhonian thesis is also not self refuting because the sceptic arguments are only an expression of the sceptic mind; they do not have a claim for objectivity and truth; the arguments are only representative of what appears at the moment to the sceptic mind. The Pyrrhonian thesis has a subjective character. ${ }^{6}$

So far so good, as long as we share a sceptical relativistic perspective both in epistemology and in ethics.The problem starts in the sphere of morality with happiness (eudaimonia) as the tranquility of the soul (ataraxia). Sextus claims that the suspense of judgement which is a consequence of subjectivity enables the sceptic to reach the tranquility of the soul. The tranquility of the soul is the goal of the sceptic and of course also the consequence of the suspense of judgement as to moral issues, as to what is good and bad by nature. ${ }^{7}$ So the goal is reached by the suspense of judgement. One does not suspend judgement in order to reach the goal but sceptical arguments lead the sceptic into a suspense of judgement which brings about the tranquility of the soul. The question is: Why should anyone be more tranquil if he is in a tentative state of agnosticism as to external realities? The Pyrrhonian response is: Because if one is convinced that he holds a belief as to what is good and bad by nature, as to what is objectively and/or universally good and bad, he will hold on to that belief so intensely that he will be in a fear of losing this belief; if one intensely pursues to hold a belief as to what is good and bad by nature, as to what is objectively and/or universally good and bad because he believes that there is such a thing but is not convinced that he holds such a belief, he will be frustrated and dissappointed and will also think that he is tormented by things that are by nature bad. In any case his soul will be in a state of disturbance and trouble (tarache), not in a state of tranquility. But the sceptic who suspends judgement will only experience certain minor unavoidable troubles such as thirst and hunger and even regarding such unavoidable troubles he will escape them more mildly because he

\footnotetext{
${ }^{6}$ Sextus Empiricus: Outlines of Pyrrhonism Book 1, Section 1, 19-28

${ }^{7}$ Sextus Empiricus: Outlines of Pyrrhonism Book 1, Section 4, 12, Book 3, Section 24; Against the Ethicists, Section 4-5
} 
Journal of Ancient Philosophy Vol. VI 2012 Issue 1

will not hold a belief that they are bad by nature. Regarding avoidable issues, he will eliminate trouble as a whole.

Obviously why should someone who is convinced that he holds a belief as to what is good and bad by nature, as to what is objectively and/or universally good and bad, necessarily be in a fear of losing this belief? On the contrary he may be very confident that he will never lose this belief or this so called apprehension of what really is the case objectively and/or universally. Similarly why should someone who intensely pursues to hold a belief as to what is good and bad by nature, as to what is objectively and/or universally good and bad but is not convinced that he holds such a belief, necessarily be frustrated and dissappointed? On the contrary he may pursue such absolute realities without ever feeling frustrated and dissappointed, feeling tranquil and/or happy within the struggle, for the sake of the struggle towards the unattainable or towards something which may be attained one day.

The problem is whether Sextus means that all human beings who suspend judgement will be in a state of tranquility. If it is only particular Pyrrhonian sceptics, such as Pyrrho himself and his followers such as Timon, Aenesedimus, Agrippa and Sextus himself, that is fine, then we may say that Sextus is only describing the state of particular Pyrrhonian sceptics. But if he means that all human beings who agree with the Pyrrhonian sceptical arguments will necessarily be in a state of tranquility, that would be a gross generalization and also be in conflict with his own phenomenalistic subjectivist perspective. This would also be in contradiction with what he says on induction. Sextus says that inductive inferences are shaky because in such an inference the universal conclusion is derived from limited particulars; since particulars are boundless and one can not consume all particulars and one particular may be in conflict with the universal, inductive inferences can never be considered reliable. ${ }^{8}$ So to make an inductive generalization about the human being or human soul would also be in contradiction with his own view on induction. Sextus never makes it very clear whether he makes an inductive generalization about the human soul or whether he limits his conclusion about the transition from the suspense of judgement to the tranquility of the soul to particular sceptical philosophers.

\footnotetext{
${ }^{8}$ Sextus Empiricus: Outlines of Pyrrhonism Book 2, Section 15
} 
Journal of Ancient Philosophy Vol. VI 2012 Issue 1

Factually it is very clear that not all sceptics who agree with the Pyrrhonian arguments would necessarily be in a state of tranquility, on the contrary, many would be in a state of disturbance and anxiety. But in any case even if we assume that he does not make such a generalization as a fact one could still question the Pyrrhonian goal of tranquility, one could question why we ought to accept such a goal in life and whether such a goal is compatible with a more accurate analysis of the being of the human being.

The question and problem is: Why tranquility? Why not anxiety? Why pleasure? Why not pain? Why happiness? Why not unhappiness? Human reality seems to cover a variety of feelings and can not be reduced either as a fact or as a goal to one particular feeling such as tranquility, pleasure, happiness or their opposites.

The existentialism of the 19th and 20th centuries is a striking example and a serious challenge to Ancient Greek ethics. The theories of Friedrich Nietzsche, Soren Kierkegaard, Karl Jaspers, Martin Heidegger, Gabriel Marcel and Jean-Paul Sartre suggest a completely different understanding of life and the human being. Obviously there are some important differences among these philosophers and it is debatable whether we could categorize and generalize these philosophers under the title existentialism. As a matter of fact it is mostly Sartre who uses the term existentialism to describe his ontology. However there are particular similarities and intersecting points among these philosophers which may enable us to use the term existentialism to describe a particular perspective derived from their ideas. ${ }^{9}$ When I say existentialism in this paper, I do not refer to the theories of these philosophers as a whole.

Besides significant differences, the essential common points among these philosophers can be summarized as follows: ${ }^{10}$

9 There are scholars who share this opinion and conduct research from this perspective. Six Existentialist Thinkers by H.J. Blackham and Existentialism by David Cooper are two significant works which were written in this framework.

${ }^{10}$ My analysis is not identical to that of Blackham and Cooper but has some similarities. The points I present are expressed in various forms at numerous passages in the works of Nietzsche, Kierkegaard, Jaspers, Marcel, Heidegger and Sartre; particularly in Kierkegaard's Concluding Unscientific Postscript, The Present Age, The Sickness Unto Death, The Concept of Anxiety, Fear and Trembling; in Nietzsche's Human All Too Human, Beyond Good and Evil, The Gay Science, The Genealogy of Morality, Twilight of the Idols, The Anti-Christ; in Heidegger's Being and Time, An Introduction to Metaphysics; in Jaspers' The Perennial Scope of Philosophy, Philosophy of Existence, Reason and Exiztenz, Philosophy; in Marcel's Being and Having, The Mystery of Being, The Existential 
Journal of Ancient Philosophy Vol. VI 2012 Issue 1

1) The prior task of philosophy should be to present an analysis of the being of the human being.

2) Subjectivity is the essential characteristic of the human being; the human being can not be understood as a whole in purely objective terms.

3) The human being is always in a state of becoming, a potentiality, through choice and action, not in a state of being as a fixed, stable, changeless creature.

4) The feeling of anxiety and/or anguish and/or metaphysical fear and/or spiritual pain is an essential aspect of the human being.

5) Alienation and inauthenticity are as much part of life as authenticity.

These are also the main and basic principles of what I call existentialism and they need not to be identified with other definitions of existentialism. The first and second points do not pose a serious threat to Pyrrhonism; they are even compatible with it. But the third, fourth and fifth points stand as something incompatible with the Pyrrhonian view on the tranquility of the soul as the goal of life and as the consequence of the suspense of judgement on moral issues. These latter points obviously are also not compatible with any type of eudaimonism and/or hedonism in Ancient Greek philosophy; existentialism is not only a threat to Pyrrhonism but also a threat to Plato, Aristotle, Zeno (of Citium) and Epicurus. (I believe the first and second points, depending on our interpretation, may also pose a challenge to these philosophers.)

One may make a distinction between is and ought and say that the goal in Ancient Greek ethics is always about an ought, about the normative aspect of moral philosophy, about an ideal, not about a factual description of how things are. This is correct and it is also correct that existentialism often makes no normative statement, it usually does not set a moral goal for life; that is definately the case in Heidegger's Being and Time and Sartre's Being and Nothingness. What they do here is to present a phenomenological and ontological description of the being of the human being; of what it means to be a human being; of what it is to be a human being. But the question is, how can one set a moral goal, as it is the case in Ancient Greek philosophy and also in Pyrrhonism, without an accurate description and analysis of the

Background of Human Dignity, The Philosophy of Existentialism; and in Sartre's Being and Nothingness, Existentialism is a Humanism. 
Journal of Ancient Philosophy Vol. VI 2012 Issue 1

being of the human being; of what it means to be a human being; of what it is to be a human being? How can one develop an ought without having an accurate grasp of what is? In this case, isn't eudaimonism and also hedonism (regardless of whether they are in contrast to each other or not) just an artificial and fake goal, something never to be attained, something representing a wishfull thinking, something incompatible with human nature?

The human being is always in a state of becoming, not in a state of being as a fixed, stable, changeless creature; he is always a potentiality, he is always something he is not yet, always with an intention and projection towards the future, seperated from something fixed, stable and changeless by a nothingness. ${ }^{11}$ Thus from an existentialist perspective it makes no sense to talk about some fixed goal and state such as happiness or pleasure or tranquility. Furthermore, anxiety and/or anguish is part of the human condition as a result of this potentiality and neither anxiety nor anguish are compatible with happiness, pleasure and tranquility. The disturbed and troubled state of the soul which the Pyrrhonians talk about may not be identical to what the existentialists call anxiety and anguish; similarly the feeling of pain in Pyrrhonism or in Ancient philosophy in general may not be identical to anxiety and anguish either; the Ancient Greek terms seem to refer to something more general and the existentialist terms to something more specific, such as in Heidegger when he establishes a relationship between being-towards-death (sein-zum-tode) and anxiety (angst). Furthermore the existentialists distinguish between fear and anxiety; they say, anxiety, unlike fear, has no object; one can fear something but not feel anxiety about something concrete and particular; the Pyrrhonians on the other hand, like the Epicureans, seem to include the feeling of fear within a troubled and disturbed state of the soul. But eventually we may easily say that the existentialist terms anxiety and anguish do not represent a tranquil state of the soul either; they do represent some sort of disturbance and trouble even if not related to other feelings which can also be categorized under a troubled and disturbed state of the soul. Finally, alienation, both in the sense of losing authenticity and in the sense of losing freedom or the consciousness of freedom is another part of the human condition. It is debatable whether a person can be considered to be happy or to feel pleasure or to be tranquil when he is in a state

\footnotetext{
${ }^{11}$ Martin Heidegger: Being and Time, Part 1, Division 1, Chapter 1, Section 9-11; Part 1, Division 2, Chapter 1, Section 46-53; Jean-Paul Sartre: Being and Nothingness, Part 1, Chapter 1, Section 5
} 
Journal of Ancient Philosophy Vol. VI 2012 Issue 1

of alienation and inauthenticity. How can a person be happy or feel pleasure or be tranquil if he is detached from himself, from his distinctive individual characteristics, if he loses his identity in public, in the masses, in the others, if he escapes from his freedom, if he becomes anonymous, mediocre and ordinary, if he can not create his own values?

One objection may be that the Pyrrhonians as well as the Ancient Greek philosophers in general did not have to deal with such concepts as anxiety, anguish, alienation and authenticity; simply because they never experienced such states in their soul; that such feelings are only part of the modern man and the modern world. I have strong doubts about this view. It is correct that such terms and themes became more a part of the philosophical scene in the 19th and 20th centuries; but that does not mean that those feelings and states of the soul never existed before among human beings. It is highly possible that they did exist in Ancient Greece as well; that the same human conditions were present at that time as well; that the obsessive search for happiness, pleasure and tranquility was probably a consciouss or unconsciouss consequence of the presence of those conditions as well.

Based on the same reasons, establishing a goal towards happiness, pleasure and tranquility should not be seen as a surprise; but again, the question is, how natural, how realistic would such an attempt be? If such attempts are incompatible with human nature, wouldn't it be more disappointing for a human being to set such a goal and never achieve it? How happy and how tranquil can a person be if he sets a goal which is unattainable, which is against human nature, against the natural human condition? The struggle to overcome alienation and inauthenticity is obviously among the most admirable and honourable things in the history of humanity and this struggle should obviously be preserved as long as humanity exists; but the obsession to transcend our fears, pains and anxieties is not only artificial and unnatural but is also against the spirit of a struggle to overcome alienation and inauthenticity. Fear, pain and anxiety is an essential part of this struggle, the person who has a concern for freedom must necessarily be in a state of fear, pain and anxiety, at least occasionally or frequently, if not on a continious basis.

Another crucial aspect is the effect of the sceptical epistemic condition on the human soul and his psychological state. Not being able to know what is going on out there in the external world at an objective and/or universal level, on the contrary only being aware and consciouss of our appearances, may cause more anxiety and anguish than tranquility or peace 
Journal of Ancient Philosophy Vol. VI 2012 Issue 1

of the soul. Not being able to know how things are in themselves independent of the mind, not being able to know what is morally good and bad independent of our personal subjective convictions, not being able to know the future due to the problem of induction, not being able to know whether there is a God or not ${ }^{12}$ can terrify most people and make them more anxious. How can ambiguity and uncertainty be a source of tranquility? Why should it be? Why tranquility? Why not anxiety?

One alternative is to defeat the sceptical arguments stated by the Pyrrhonians. As a matter of fact many philosophers made that attempt. But how successfull have they been? Isn't that artificial as well? Aristotle stated in his work titled Metaphysics that all human beings have a natural tendency to understand, to know; but the Pyrrhonian arguments shows us that understanding and knowing has its limits as well; that one can not transcend his appearances. (If both Aristotle and the Pyrrhonians are correct in this particular point, the result can be considered as the tragedy of the human being). The 18th century philosopher David Hume was one of the few philosophers who saw and accepted the force of the Pyrrhonian arguments. He thought that only passion, natural instinct and the feeling of belief can save us from the force of Pyrrhonian arguments; the struggle against Pyrrhonian epistemology and ethics through pure reason and rational argumentation, as it has been the case with most rationalist philosophers, is a lost battle. ${ }^{13}$ Nietzsche was also one of the few philosophers to agree with scepticism in general and also with Pyrrhonian scepticism in particular; particularly with its challenge against the artificial duality created between appearance and reality, with its arguments against a criterion of truth; declaring Pyrrho as the only original philosopher after the Pre-Socratics to protest against the doctrines of Plato; declaring the Ancient Sceptics as the only honourable type in the history of philosophy. ${ }^{14}$

Aside from Hume and Nietzsche, I do agree with the sceptical arguments of the Pyrrhonians. There is no need and no convincing way to challenge the epistemological aspect

\footnotetext{
${ }^{12}$ Sextus Empiricus: Outlines of Pyrrhonism, Book 3, Section 2-3

${ }^{13}$ David Hume: An Enquiry Concerning Human Understanding, Chapter 12

${ }^{14}$ Friedrich Nietzsche: Ecce Homo, Part 3; Anti-Christ, Section 12 and 54; The Gay Science, Section 110, 354; Genealogy of Morality, Preface, Section 3; Human All Too Human, Section 21; Will To Power, Section 437; On Truth and Lies in A Nonmoral Sense; Twilight of the Idols, The Problem of Socrates, Section 2,4,10, 'Reason' in Philosophy, Section 6, 19; Beyond Good and Evil, Section 34
} 
Journal of Ancient Philosophy Vol. VI 2012 Issue 1

of Pyrrhonism, particularly the problem of infinite regress. The problem is not the scepticism inherent in their epistemology; the problem is not the epoche; the problem is with the concept of ataraxia, with the telos and the so called consequence of epoche. Existentialism poses an important challenge to that aspect and Pyrrhonism can make use of that aspect without demolishing itself as a whole. This may be seen as a process of evolution throughout time. If it wants to survive, it must adapt and reconstruct itself.

So must existentialism. Pyrrhonism and existentialism need each other. Pyrrhonism needs to give up the concept of ataraxia and replace it with tarache as anxiety; not as a telos but as a mere consequence of epoche. Existentialism on the other hand needs a sceptical epistemological backbone, not a so called vague phenomenological and ontological explanation. Existentialism needs to replace Edmund Husserl's phenomenology with Pyrrhonian phenomenalism and it needs to supplement its ontology with a sceptical epistemology. For who? Of course for the existentialist Pyrrhonians and Pyrrhonian existentialists only. Because the problem of induction in relation to human nature remains unsolved. If the tranquility of the soul is only valid for particular Pyrrhonian sceptics and if it is not a generalization, if it is only a description of a psychological state of particular people and does not include an inference from particulars to a universal, that is fine. But if the tranquility of the soul is presented as a necessary consequence of the suspense of judgement for all people, that is definately not a very convincing analysis about the human being. Neither is anxiety a necessary consequence of doubt for all people.

An existential analysis of the human being shows us that the human being is a being which chooses and acts. As the famous existentialist saying goes, existence preceeds essence; there is no fixed human nature; man defines himself with his acts and choices; man is condemned to freedom; he is always in a state of choice with an intention and a project towards the future. ${ }^{15}$ That is correct but it is also clear that existentialism generally lacks a morality, an ethics with a normative aspect, an ethics with a goal. Existentialism does not only lack an epistemology but usually also a normative ethics, at least in particular major works such as Being and Time and Being and Nothingness. The overcoming of alienation and

\footnotetext{
${ }^{15}$ Martin Heidegger: Being and Time, Part 1, Division 1, Chapter 6, Section 40; Jean-Paul Sartre:
} Being and Nothingness, Part 4, Chapter 1, Section 1-3; Existentialism is a Humanism 
Journal of Ancient Philosophy Vol. VI 2012 Issue 1

inauthenticity is rarely presented as a moral goal. Pyrrhonism has a moral goal, namely the tranquility of the soul, but it is a weak and fake goal; existentialism usually has no goal at all, at least not in early Heidegger and Sartre, it is just worried with a descriptive aspect, with the is, not with the ought. Therefore, an existentialist reconstruction of Pyrrhonism or a Pyrrhonian reconstruction of existentialism or if we may say so a synthesis between existentialism and Pyrrhonism also needs the establishment of a moral goal. This goal is neither happiness nor unhappiness, neither pleasure nor pain, neither tranquility nor disturbance. The goal is simply freedom in the sense of overcoming alienation and inauthenticity. As Sartre says, man is condemned to freedom in the sense that he is always in a state of choice with an intention and a projection towards the future; but that is not enough to explain freedom in another sense; the choice needs to be an authentic and non-alienated choice, not just any choice. To supplement this with an aspect in Nietzsche, who is actually not a nihilist as many scholars assume, the goal is freedom in the framework of a worldly, life affirming spirit, with an ability to create our own personal values, without any need to invent universalistic and/or objectivistic moral truths, without any need to invent metaphysical and/or religious other worlds, without any need to invent a life beyond this life we are living in; without negating life; this life being a life of happiness and unhappiness, pleasure and pain, tranquility and disturbance. ${ }^{16}$ The existence of all these conditions is a precondition for the possibility of a struggle for freedom. The quest for freedom is necessary because of our awareness of unhappiness, pain and disturbance due to the occasional existence of their opposites; or vice versa, the quest for freedom is necessary because of our awareness of happiness, pleasure and tranquility due to the occasional existence of their opposites. Whether freedom does produce happiness, pleasure or tranquility is not relevant at this stage and one may never know if it will produce happiness, pleasure or tranquility in each person.

\footnotetext{
${ }^{16}$ Friedrich Nietzsche: Twilight of the Idols, The Problem of Socrates, Section 4, 'Reason' in Philosophy, Section 1, 6, Morality as Anti-Nature, Section 1,4, The Four Great Errors, Section 8, What I Owe To the Ancients, Section 2; Beyond Good and Evil, Preface, Section 62, 168, 202, 203, 269; Human All Too Human, Section 114, 115, 125, 129, 132, 141, 150, 225, 261; On the Genealogy of Morality, Second Essay, Section 24, Third Essay, Section 17; Anti-Christ, Section 7-9, 18, 51-52, 55 .
} 
Journal of Ancient Philosophy Vol. VI 2012 Issue 1

Regardless of whether freedom will produce happiness, pleasure and tranquility, is it possible to achieve such a goal? Is freedom as an absolute elimination of alienation and inauthenticity a possibility? As a good sceptic we can never know that for sure either. But the struggle for freedom is itself an important and attractive value because this struggle is the only thing in life which raises a consciousness of the potentiality of the human being. The point is not to reach the summit, but rather to do the climbing, to experience the process. Both Pyrrhonism and existentialism can offer us a lot towards that direction.

\section{Bibliography}

Annas, Julia \& Barnes, Jonathan. The Modes of Scepticism. Cambridge University Press, 1985.

Annas, Julia. Hume and Ancient Scepticism. (In Ancient Scepticism and the Sceptical Tradition, Edited by Juha Sihvola). Acta Philosophica Fennica 66, 2000.

Burnyeat, Myles (Editor). The Sceptical Tradition. University of California Press, 1983.

Empiricus, Sextus; (Translated by Annas, Julia \& Barnes, Jonathan); Outlines of Scepticism; Cambridge University Press, 1994.

Empiricus, Sextus; (Translated by Bury, R.G.); Outlines of Pyrrhonism; The Loeb Classical Library, Harvard University Press, 1933.

Empiricus, Sextus; (Translated by Bury, R.G.); Against the Ethicists; The Loeb Classical Library, Harvard University Press, 1936.

Empiricus, Sextus; (Translated by Bett, Richard); Against the Ethicists; Clarendon Press, 1997.

Empiricus, Sextus; (Translated by Mates, Benson); Outlines of Pyrrhonism; Oxford University Press, 1996.

Hallie, Philip P. (Editor) \& Etheridge, Sanford G. (Translator). Scepticism, Man and God. Wesleyan University Press, 1964.

Hankinson, R.J. The Sceptics. Routledge, 1998.

Heidegger, Martin; Introduction to Metaphysics; Yale University Press, 1959.

Heidegger, Martin; Being and Time; Blackwell, 1962.

Heidegger, Martin; History of the Concept of Time; Indiana University Press, 1985.

Hookway, Christopher. Scepticism. Routledge, 1990. 
Journal of Ancient Philosophy Vol. VI 2012 Issue 1

Hume, David; A Treatise of Human Nature; Clarendon Press, 1978.

Hume, David; Enquiries Concerning Human Understanding and Concerning the Principles of Morals; Clarendon Press, 1975.

Hume, David; Dialogues Concerning Natural Religion; Penguin Books, 1990.

Jaspers, Karl; The Perennial Scope of Philosophy; Yale University Press, 1950.

Jaspers, Karl; Philosophy of Existence; University of Pennsylvania Press, 1971.

Jaspers, Karl; Philosophy; University of Chicago Press, 1971.

Jaspers, Karl; Reason and Exiztenz; Marquette University Press, 1996.

Kierkegaard, Soren; Concluding Unscientific Postscript; Princeton University Press, 1971.

Kierkegaard, Soren; Fear and Trembling; Princeton University Press, 1983.

Kierkegaard, Soren; The Sickness Unto Death; Doubleday, 1954.

Kierkegaard, Soren; The Present Age; Harper \& Row, 1962.

Kierkegaard, Soren; Either / Or; Princeton University Press, 1974.

Kierkegaard, Soren; The Concept of Anxiety; Princeton University Press, 1980.

Kierkegaard, Soren; Philosophical Fragments; Princeton University Press, 1985.

Long, A. A. \& Sedley, D. N. The Hellenistic Philosophers Volume 1. Cambridge University Press, 1987.

Marcel, Gabriel; Being and Having; Dacre Press, 1949.

Marcel, Gabriel; The Mystery of Being; The Harvill Press, 1951.

Marcel, Gabriel; The Existential Background of Human Dignity; Harvard University Press, 1963.

Marcel, Gabriel; The Philosophy of Existentialism; Carol Publishing Group, 1995.

Naess, Arne. Scepticism. Routledge and Kegan Paul, 1968.

Nietzsche, Friedrich; On Truth and Lies in a Nonmoral Sense (in Epistemology: The Classic Readings, Edited by David Cooper); Blackwell, 1999.

Nietzsche, Friedrich; Human, All Too Human; Penguin Classics, 1994.

Nietzsche, Friedrich; The Gay Science; Vintage Books, 1974.

Nietzsche, Friedrich; Beyond Good and Evil; Penguin Classics, 1990.

Nietzsche, Friedrich; On the Genealogy of Morality; Cambridge University Press, 2005.

Nietzsche, Friedrich; Twilight of the Idols / The Anti-Christ; Penguin Classics, 1990.

Nietzsche, Friedrich; Ecce Homo, Penguin Classics, 1992.

Nietzsche, Friedrich; The Will to Power; Vintage Books, 1968. 
Journal of Ancient Philosophy Vol. VI 2012 Issue 1

Öymen, Örsan K. Sextus Empiricus' Problem of Criterion. PhD Thesis: Middle East Technical University, Department of Philosophy, 1999.

Öymen, Örsan K., Sekstus Empirikus'un 'Pironizmin Ana Hatlart' Eserinden Bölümlerin Çevirisi Üzerine, (On the Translation of Parts from Sextus Empiricus' 'Outlines of Pyrrhonism'), Yeditepe'de Felsefe, 2003.

Öymen, Örsan K., Varoluşun Temeli Olarak Skeptisizm (Scepticism as The Foundation of Existentialism), Felsefe Logos, 2003.

Öymen, Örsan K., Varoluşçuluğun Varoluşu (The Existence of Existentialism), Felsefe Logos, 2006.

Öymen, Örsan K. Kuşkuculuk Bağlamında Pironculuk-Hume-Nietzsche İlişkisi (The Pyrrhonism-Hume-Nietzsche Connection in the Framework of Scepticism), Baykuş Dergisi, 2009.

Popkin, Richard. The High Road to Pyrrhonism. Hackett, 1993.

Rescher, Nicholas. Scepticism. Rowman \& Littlefield, 1980.

Sartre, Jean-Paul; Existentialism is a Humanism; Yale University Press, 2007.

Sartre, Jean-Paul; Being and Nothingness; Washington Square Press, 1956.

Sartre, Jean-Paul; The Transcendence of the Ego: An Existentialist Theory of Consciousness; Noonday, 1957.

Sartre, Jean-Paul; Sketch for a Theory of the Emotions; Methuen, 1962.

Striker, Gisela. Essays on Hellenistic Epistemology and Ethics. Cambridge University Press, 1996.

Williams, Michael. (Editor). Scepticism. Dartmouth, 1993 